\title{
Religija i Internet — novi izazovi življenja vjere
}

\author{
Krunoslav Novak*, Jerko Valković**
}

\begin{abstract}
Sažetak
Novi mediji nisu samo sredstvo komuniciranja, nego »ambijent« u kojem svakodnevno "žive" milijuni ljudi širom svijeta. To je prostor u kojem se razvijaju novi načini komuniciranja, novi oblici povezivanja i oblikuju nova zajedništva. Polazeći od činjenice da živimo $» u \ll i » s$ « virtualnim svijetom te da on snažno utječe na naš svakodnevni život, autori promišljaju o tome kako život u virtualnom svijetu utječe na iskustvo vjere. Posebnu pozornost posvećuju utjecaju internetske komunikacije na neke važne odrednice vjere: virtualni simbolički kontekst, novi oblici zajednišstva, pitanje autoriteta, individualizacija i osjećaj pripadnosti.

Ključne riječi: religija i Internet, religija online, online religija, autoritet, zajednica, pripadnost
\end{abstract}

\section{Uvod}

Gotovo sve vjerske zajednice prepoznale su važnost novih medija, kako za osobni, tako i društveni život, te su na različite načine prisutne u tom »virtualnom kontinentu«. Neke zajednice, poput Katoličke crkve, sustavno promišljaju o izazovima i mogućnostima komunikacije putem novih medija, s posebnim naglaskom na evangelizacijsko-pastoralnim, antropološkim, etičkim i odgojnim aspektima. ${ }^{1}$ Crkva je svjesna da komunikacija putem Interneta označava novu

* Dr. sc. Krunoslav Novak, Odjel za komunikologiju, Hrvatsko katoličko sveučilište. Adresa: Ilica 242,10000 Zagreb, Hrvatska. E-pošta: krunoslav.novak@unicath.hr

** Izv. prof. dr. sc. Jerko Valković, Odjel za komunikologiju, Hrvatsko katoličko sveučilište. Adresa: Ilica 242,10000 Zagreb, Hrvatska. E-pošta: jerko.valkovic@unicath.hr

1 Spomenut ćemo neke važnije dokumente koji se odnose na tu temu: Papinsko vijeće za društvena obavijesna sredstva, Crkveni dokumenti o internetu - Etika na Internetu. Crkva i Internet, Zagreb, 2003; Ivan Pavao II., Deset poruka za slavlje svjetskog dana sredstava društvene komunikacije, Zagreb, 2003; Benedikt XVI., Mediji: mreža komunikacije, zajedništva i suradnje, Poruka za 40. svjetski dan sredstava društvenih komunikacija (2006.), IKA, 01. veljače 2006, 5, 27-28.; Benedikt XVI., Nove tehnologije, novi odnosi. Promicati kulturu poštivanja, dijaloga i prijateljstva, Poruka za 43. svjetski dan sredstava društvenih komunikacija (2009.), u: IKA, 04. ožujka 2009, 9, 26-27.; Benedikt XVI., Istina, navještaj i autentičnost života u digitalnom dobu, Poruka za 45. svjetski dan sredstava društvenih komunikacija (2011.), u: IKA, 16. veljače 2011, 7, 30-31.; Benedikt XVI., Društvene mreže: vrata istine i vjere; novi prostori evangelizacije, Poruka za 47. svjetski dan sredstava društvenih komunikacija (2013.), u: IKA, 20. veljače 2013, 8, 25-30. 
komunikacijsku »paradigmu«, da omogućava drugačije načine komuniciranja unutar same Crkve i Crkve sa svijetom, ali i novi način prisutnosti Crkve u javnosti. Papa Benedikt XVI., imajući u vidu spomenute promjene, kao da ide još jedan »korak dalje«. Obraćajući se članovima Papinskog vijeća za sredstva društvenih komunikacija, on poziva na promišljanje o novostima i izazovima koje »digitalni kontinent « predstavlja za konkretno življenje vjere, kao i za teološko promišljanje. ${ }^{2}$ Naime, ako život unutar virtualnih prostora utječe na naš način življenja i razmišljanja, ne utječe li — pita se isusovac Antonio Spadaro na tragu papinih riječi — i na način promišljanja i življenja vjere? ${ }^{3}$

\section{Religija na pragu virtualnog prostora}

Prvi »susreti« religije i Interneta ostvareni su se prije više desetljeća. Pozivajući se na Rheingolda, talijanski sociolog religije Enzo Pace kaže da se početci prisutnosti religije na Internetu mogu povezati s oblikovanjem prvih virtualnih zajednica koje su raspravljale o vjerskim temama. Rheingold govori o prvim (religijsko usmjerenim) aktivnostima u Bulletin Bord Systems ${ }^{4}$ (s pomalo provokativnim nazivom »Oblikuj vlastitu religiju « na forumu CommuniTree). ${ }^{5}$ Koju godinu kasnije, oko 1985., počeli su se brzo širiti tzv. net-religion forumi, na kojima se raspravljalo o religijskim, etičkim i moralnim temama. Kao primjer spominjemo Metodističku crkvu u Americi, koja kreira i prvi $e$-mail newsletter, koji je trebao poslužiti vjernicima kao servis informacija (United Methodist Information). ${ }^{6}$

Prva »crkva" na internetskim prostorima oblikuje se 1994. kada Henderson pokreće web-stranicu koju je nazvao The First Church of Cyberpace (riječ je o američkoj prezbiterijanskoj crkvi (URL: http://www.godweb.org/sact.html). Kada je godine 1996. magazin Time objavio posebni broj Jesus Online, tada već nalazimo desetine mrežnih stranica koje su posvećene vjerskim temama. Spomenimo prvu monašku mrežnu stranicu Monastery of Christ in the Desert (URL: http://www.christdesert.org), kao i prvi islamski e-periodični časopis: Renaissance: A Monthly Islamic Journal (URL: http://www.renaissance.com.pk). ${ }^{7}$

2 Usp. Discorso del Santo Padre Benedetto XVI ai partecipanti all'assemblea plenaria del Pontificio consiglio delle comunicazioni sociali, 28. veljače 2011. URL: https://w2.vatican.va/content/benedict-xvi/it/speeches/2011/february/documents/hf_ben-xvi_spe_20110228_pccs.html (preuzeto 15.12.2015.)

3 Usp. A. Spadaro, Cyberteologia. Pensare il cristianesimo al tempo della rete, Milano, 2012, 9. To da se i u akademskim krugovima raspravlja o spomenutoj temi govori i činjenica da na Papinskom sveučilištu Gregorijana u Rimu Spadaro predaje kolegij »La Cyberteologia: pensare il cristianesimo al tempo della rete «.

4 Riječ je o elektroničkoj oglasnoj ploči, odnosno računalnom sustavu s programom koji omogućava korisnicima da se povežu i prijave. Možemo reći da su na svoj način BBS-ovi bili prethodnica modernomu obliku Weba i drugih aspekata Interneta.

5 Usp. E. Pace, La comunicazione invisibile. Le religioni in Internet, Cinisello Balsamo, 2013, 30-31.

6 Isto, 35.

7 U tekstu naslovljenom Finding God on the Web Chama svjedoči da je pisanje na Internetu o religijskim temama u ono vrijeme za mnoge bila velika i izazovna zadaća. To je prostor u kojem se 
Katolička crkva »službeno« stupila je u svijet Interneta za Božić 1995., kada je na službenim vatikanskim stranicama (www.vatican.va) objavljena Papina božićna poruka. Ubrzo je bila pokrenuta i vatikanska stranica koja je posebno namijenjena mladima (Pope2you), a nešto kasnije, u svibnju 2011. godine, i vatikanski Twitter portal (TwitterŽPSSC_VA).

Danas su gotovo sve vjerske zajednice prisutne u virtualnom svijetu. ${ }^{8}$ Međutim, različiti su ciljevi koje te zajednice žele ostvariti internetskom komunikacijom. Istražujući njihov sadržaj, Menicocci ističe četiri osnovne funkcije: ${ }^{9}$

— Predstavljaju život i djelovanje zajednice (osobito onima koji nisu pripadnici tih zajednica, obavljajući pritom funkciju »odnosa s javnošću«).

— U službi su evangelizacije.

- Pridonose jačanju povezanosti između članova vjerske zajednice i omogućavaju produbljenje vjere (primjerice pružaju mogućnost razmjene sadržaja). Ta je funkcija za Menicoccija najvažnija.

- Takve su web-stranice vrijedan izvor za znanstvena proučavanja jer sadržavaju dokumente ili druge tekstove do kojih je inače teže doći (primjerice Biblija na različitim jezicima, dokumenti, komentari i dr.).

Kakve će komunikacijske oblike pojedine vjerske zajednice preferirati i koje će funkcije imati njihove mrežne stranice ovisi ne samo o mogućnostima koje pružaju novi mediji nego i o razini svijesti važnosti komunikacije unutar zajednica.

U ovom tekstu posebnu pozornost želimo usmjeriti prema virtualnom prostoru kao simbolično-društvenomu kontekstu u kojem današnji čovjek živi svoju vjeru. Odnos prema istini (vjere), iskustvo pripadnosti i sudjelovanja u (virtualnom) zajedništvu, eklezijalna pripadnost i odnos prema (vjerskom) autoritetu neke su od važnih odrednica velike većine religijskih zajednica. Utječe li život unutar virtualnog prostora na način doživljavanja i ulogu spomenutih odrednica? Ako se u potpunosti i ne složimo s tvrdnjom Dawsona i Cowana da Internet mijenja shvaćanje religije, potrebno je suočiti se s izazovima pred koje nas stavlja. ${ }^{10}$

»ideje o Bogu i vjera mogu širiti, gdje se vjera može oblikovati i definirati kao kolektivni duh«. J. R. Chama, Finding God on the Web, u: Time, 149 (1996) 1, 57.

8 O prisutnosti vjerskih zajednica na Webu u Hrvatskoj vidi tekst: N. Duvnjak, Načini prezentacije vjerskih zajednica u Hrvatskoj na internetu: analiza kvalitete mrežnih mjesta, u: Crkva u svijetu, 50 (2015) 1, 57-82. Koristan je i tekst koji pruža uvid u mrežne stranice (nad)biskupija u Hrvatskoj: N. Palac, Hrvatske (nad)biskupije na društvenim mrežama, u: Crkva u svijetu, 50 (2015) 2, 324-344.

9 Usp. M. Menicocci, La rete delle Religioni, br. 4.0 4.6. Storiadelmondo, n. 33, 28 marzo 2005. URL: http://www.storiadelmondo.com/33/menicocci.religioni.pdf (preuzeto 21.12.2015.)

10 L. Dawson - D. Cowan (ur.), Religion Online: Finding Faith on the Internet, Routledge, New York 2004, 1. 


\section{Istraživanja o religiji na Internetu}

Iako Campbell tvrdi da se religioznost današnjeg čovjeka ne može razumjeti ukoliko se ne razumije način na koji on živi vjeru u virtualnim prostorima (drugim riječima to je nužno za istraživanje bilo kojeg aspekta religioznosti) ${ }^{11}$ još uvijek nisu tako brojna istraživanja koja su posvećena toj problematici. ${ }^{12}$ Taj manjak donekle može opravdati činjenica veoma brzog razvitka medija i snažne interakcije koju oni ostvaruju na svim područjima. Zbog toga je ponekad teško pratiti i jasno razlučiti izvore pojedinih utjecaja. Uz to se kod istraživanja susrećemo i s poteškoćama metodološke naravi. Kako obuhvatiti tako široki korpus informacija i kako ih vrednovati? Prema kojem bi kriteriju trebalo odrediti što doista spada među informacije vjerskog sadržaja? ${ }^{13}$

Treba svakako imati na umu da se već i shvaćanje Interneta i njegove uloge od početka masovne upotrebe značajno promijenilo. To svjedoči i istraživanje o značenju Interneta koje je proveo Wellman i koje je imalo utjecaj na mnoga kasnija istraživanja. On promatra razvitak Interneta kroz tri razdoblja. ${ }^{14}$ Prvo razdoblje započinje oko 1990. i označeno je entuzijazmom zbog nepreglednih mogućnosti koje Internet nudi. U tom razdoblju još ne nalazimo dublju teoretsku refleksiju o Internetu, a važno je spomenuti da se u to vrijeme virtualni svijet doživljavao »odvojenim« od realnoga. Drugo razdoblje, koje je započelo 1998. godine, označeno je brzim širenjem Interneta, koji je prestao biti privilegij pojedinaca. U tom razdoblju nalazimo značajnija istraživanja o upotrebi Interneta (ne samo na osobnoj nego široj, globalnoj razini, primjerice World Internet Project). Sve se više uočava utjecaj i povezanost internetske komunikacije i realnog života, te se ističe utjecaj Interneta na pojedinca i društvo. U trećem razdoblju veoma se malo govori o odvojenosti stvarnog i virtualnog svijeta, a glavni je naglasak na njihovoj komplementarnosti.

$\mathrm{Na}$ analogan način Campbell promatra odnos religije i Interneta. ${ }^{15} \mathrm{U}$ prvom razdoblju istraživanja će istaknuti mogućnosti koje se u virtualnom prostoru nude za vjerske zajednice. U tom razdoblju gotovo se može govoriti o fascinira-

11 Usp. H. Cambell, Understanding the Relationship Between Religious Practice Online and Offline in a Networked Society, Journal od American Academy of Religion, 79 (2012) 1, 1-30.

12 Prva međunarodna konferencija o odnosu religije i Interneta održana je u Danskoj 2001. godine. Ubrzo nakon toga, u travnju sljedeće godine, na MIT Communications Forum raspravljalo se o istoj temi. Već je tom prigodom bilo rečeno da se o prisutnosti religije na Internetu i njihovu suodnosu posvećuje premalo pozornosti u akademskim krugovima. Usp. D. Arasa - L. Cantoni L. Adrián Ruiz (ur.), Religious internet communication: facts, trends and experiences in the Catholic Church, Roma, 2010, 16. Upućujemo također na online časopis Heidelberg Journal of Religions on the Internet dostupan na adresi URL: http://journals.ub.uni-heidelberg.de/index.php/religions/ (preuzeto 09.01.2016.)

13 Usp. F. Vecoli, Internet e religione. Una introduzione, Humanitas, 65 (2010) 5-6, 757-758.

14 Usp. B. Wellman, The Three Ages of Internet Studies: Ten, Five and Zero Years Ago, New Media \& Society, 6 (2004) 1, 123-129.; Isto, Studing the Internet through the Ages, u: M. Consalvo - C. Ess (eds.), The Handbook of Internet Studies, Oxford, 2011, 17-23.

15 H. Campbell, Internet and Religion, u: M. Consalvo - C. Ess (ur.), The Handbook of Internet Studies, Oxford, 2011, 232-250. 
nosti novim mogućnostima, koje se nude za evangelizacijsko djelovanje. Posebno se ističe mogućnost oblikovanja (novih) religija unutar virtualnog prostora (online religion). U drugom razdoblju nastojalo se definirati razlike između različitih oblika očitovanja vjere na Internetu. U tom su se vidu promatrale virtualne zajednice i načini kako je u njima moguće sudjelovati. Željelo se vidjeti kako oblici sudjelovanja u virtualnim zajednicama utječe na (offline) život vjerskih zajednica. Naposljetku, u posljednjem razdoblju, budući da se sve više uviđa da je Internet sastavni dio svakodnevnog života, kroz istraživanja se proučavalo kako pojedine vjerske »prakse« unutar virtualnog svijeta utječu na prakticiranje vjere u realnom životu. ${ }^{16}$

U ovom kontekstu susrećemo se i s novom terminologijom. Ta nova terminologija, kao plod susreta religije i Interneta, otkriva osnovne naglaske i karakteristike pojedinih razdoblja. Najprije se susrećemo s pojmom cyber religion, a nakon toga s pojmom religion online, koji se »suprotstavlja « jednomu drugomu pojmu: online religion, a danas se govori o digital religion. Pojam cyber religion u početcima je označavao sve što se odnosilo na religiju prisutno u virtualnom prostoru. Najčešce se to doživljavalo kao »alternativa« uobičajenoj vjerskoj praksi (primjerice mogućnost da se putem Interneta »posjećuju « crkve, odnosno hramovi). Takvo shvaćanje počiva na razmišljanju da je stvarno/realno potpuno odvojeno od virtualnog, što je bila karakteristika toga razdoblja.

Značajan doprinos u istraživanju religije i Interneta dao je Helland, koji je 2000. godine uveo termine religion online i online religion. ${ }^{17}$ Pod nazivom religion online misli se na vjerske zajednice koje komuniciraju unutar virtualnih prostora, a cilj je takve komunikacije informiranje o vjeri, vjerskim temama, odnosno osobama. Korištenje Interneta u tom kontekstu svodi se na komunikaciju iz jednog (središta) prema mnogima (one-to-many communication). Na taj se način nije omogućavalo ni favoriziralo sudjelovanje posjetitelja tih stranica. U pozadini pojma online religion razumijevanje je Interneta kao interaktivnog virtualnog prostora unutar kojega se obavljaju obredi (primjerice The House of Netjer, The Church of Virus). To konkretno znači da se u virtualnom prostoru provodi

16 Spomenimo i istraživanje koje su proveli Hojsgaard i Warburg. I oni ističu da se odnos religije i Interneta treba promatrati kroz različita razdoblja. Središnje pitanje koje je dominiralo u prvoj fazi odnosilo se na nove mogućnosti (evangelizacije) koje Internet pruža religiji. Njihovi su rezultati potpuno suprotni od Campbella jer, kako iznose, prevladava negativan stav jer se smatralo da religije u virtualnim prostorima imaju veoma malo mogućnosti djelovanja. U drugom periodu veća pozornost dana je osobama (a ne toliko tehnologiji) koje »ulaze « u virtualne prostore. Hojsgaard i Warburg smatraju da je mnogo važnije djelovanje osobe — a ne mogućnosti koje pruža tehnologija — jer prvenstveno osobe utječu na oblikovanje religijskih zajednica. O njima također ovise i načini pristupa i odabira tema o kojima će se raspravljati. U središte pozornosti dolazi pitanje vjerskog identiteta, odnosno autentičnosti vjerske prakse. U trećem razdoblju istraživanja nastojalo se objasniti na koji način svakodnevno korištenje Interneta može utjecati na vjerski život. U četvrtom, posljednjem razdoblju istraživanje je bilo usmjereno na to kakav je utjecaj Interneta na shvaćanje i doživljavanje (vjerskog) autoriteta. Usp. M. Hojsgaard - M. Warburg (ur.), Religion and Cyberspace, London, 2005.

17 Usp. C. Helland, Online-religion/religion-online and virtual communitas, u: J. K. Hadden — D. E. Cowan (ur.), Religion on the Internet, London, 2000, 205-224. 
obredna praksa, da se u tim prostorima moli, prakticiraju hinduističke puđe i neopoganski rituali, nude savjetovanja i duhovna vodstva te obavljaju razne cyber svećeničke službe. Dok »tradicionalne« religije preferiraju Internet kao sredstvo za prenošenje poruke, online religija živi u forumima i chatovima, blogovima, interaktivnim stranicama. Cjelokupna se komunikacija odvija (isključivo) putem simboličkog jezika tipkovnice. Riječ je o religiji koja je nastala i postoji isključivo $\mathrm{u}$ virtualnom prostoru. ${ }^{18}$

U prvom slučaju uloga Interneta svodi se na posredovanje informacija o religijskom sadržaju i izvještavanje o aktivnostima religijskih zajednica (koje postoje izvan virtualnog prostora), a u drugom slučaju riječ je o pokušaju oblikovanja i »življenja « religije unutar virtualnih prostora. Pitanje je je li moguće potpuno i jasno razdvajati religion online od online religion jer u svakodnevnom životu nalazimo elemente i prepoznajemo utjecaje jednog i drugog »oblika « religije.

Upotreba novog pojma digital religion povezana je sa sve jačim povezivanjem online i offline prostora. Tim se izrazom nastoji opisati drugačiji odnos između religije i tehnologije, medija i kulture. »Možemo predočiti digital religion kao most koji povezuje i proteže online vjersku praksu sa vjerskim kontekstima offline i obratno. «19 Digital religion određen je karakteristikama koje su tipične za online kulturu (interaktivnost, konvergentnost, sadržaji koje proizvodi audience) te karakteristikama tradicionalnih religija (sustavi vjerovanja, obredi, zajednice vezane uz određeno područje).

Danas su novija istraživanja usmjerena na posljedice koje su plod susreta različitih oblika online i offline religioznosti (ili religijske prakse). Zapravo, nastoji se vidjeti kako Internet utječe na »tradicionalne « religije, ali isto tako na koji način vjerničke zajednice (offline) utječu i transformiraju religiju u virtualnim prostorima. Posebna se pozornost $u$ današnjim istraživanjima usmjerava prema širemu društvenomu kontekstu kao prostoru u kojem pojedinci i zajednice žive svoju vjeru.

\section{Religija u virtualnom prostoru}

Svaka religija, svaka teologija i svako vjerničko iskustvo u neprestanoj je komunikaciji/interakciji s društvenim i simboličkim prostorom. Zato je veoma važno poznavati prostor, procese i karakteristike tog prostora, kako bismo mogli razumjeti osnovne elemente vjerskog života pojedinaca ili zajednice.

18 Komentirajući različite oblike online religije, Pace postavlja pitanje je li riječ samo o nekoj (virtualnoj) video igri ili doista o zajednici u čijem je središtu vjerski, odnosno duhovni sadržaj. Usp. E. Pace, La comunicazione invisibile, 88.

19 H. Campbell, Digital Religion. Understanding Religious Practice in New Media Worlds, LondonNew York, 2013, 3. 


\subsection{Društveno-simbolički kontekst}

Polazeći od brzog razvitka i značenje uloge tehnologije osobito prošlih stoljeća, možemo reći da je ono do sada na nedostatan način valorizirano u teološkom promišljanju. Tehnologija utječe ne samo na način shvaćanja svijeta, nego određuje i način doživljavanja vlastite egzistencije. »Nije moguće odvojiti ljudsko biće od njegovog materijalnog okruženja, od znakova i slika preko kojih pridaje smisao životu i svijetu. Na isti način, ne može se odvojiti materijalni svijet — i još manje njegov umjetni dio — od ideja putem kojih čovjek shvaća i upotrebljava tehnička sredstva koja je stvorio i kojima se služi «. ${ }^{20}$

Jedno od temeljnih pitanja je doživljavaju li se novi mediji (i u komunikaciji koriste) u prvom redu kao sredstvo komuniciranja ili se u njima doista prepoznaje novi društveno-simbolički prostor. ${ }^{21}$ To je važno imati u vidu jer se virtualni ambijent u mnogočemu razlikuje od »svakodnevnog «, »realnog « životnog prostora. Ulazak u virtualno okruženje ulazak je u prostor (kakofoničkih) poruka, najraznovrsnijih slika i nerijetko kontroverznih sadržaja. Virtualnomu prostoru nedostaje karakter sakralnosti i takav ambijent — polazeći od ikonografije, dizajna i cjelokupnog konteksta — puno se bolje uklapa u tržišnu logiku negoli u neki sakralni prostor. To je prostor/okruženje koje je svima dostupno, svima na »raspolaganju « — onima koji vjeruju kao i onima koji ne vjeruju. Čak nije potrebno izlaziti iz kuće i odlaziti u sakralne prostore jer se vjera može »prakticirati « iz vlastite kuće posredstvom novih tehnologija. U tom je prostoru svako iskustvo, pa i ono vjersko, na određeni način »dematerijalizirano«, dostupno putem tipkovnice.

Nalazeći se u virtualnom okruženju, i sama baština vjere izložena je različitim mogućnostima interpretacija ili čak manipulacija. Jedno od obilježja »tradicionalnih« religija je hijerarhijski organizirani sustav, ne samo kada je riječ o samoj strukturi, nego i kada je riječ o autentičnom tumačenju onoga što spada u poklad vjere. Kada se nalazimo u virtualnom prostoru, baština vjere izložena je proizvoljnim tumačenjima i interpretacijama koje nije moguće kontrolirati. To je osobito vidljivo i izazovno kada su u pitanju istine vjere. Dok su primjerice istine vjere unutar tradicionalnih religija jasno »definirane « (točno je određeno tko ih »službeno definira «), unutar konteksta virtualnog prostora moguć je bezgraničan način različitih tumačenja. Svakomu je prepušten izbor između velikog broja ponuda. ${ }^{22} \mathrm{U}$ takvoj situaciji velika je sloboda ostavljena svakoj osobi, koja može

20 P. Levi, Cybercultura. Gli usi sociali delle nuvoe tecnologie, Milano, 1999, 26.

21 Padula tvrdi da se novost medija ne sastoji ponajprije od tehnologije, nego od različitih utjecaja na društvenom i antropološkom planu (novi oblici društvenosti i novi način preko kojega se gleda cjelokupno okruženje). Usp. M. Padula, Immersi nei media. Il nuovo modo di essere vivi, Soveria Mannelli, 2009, 89.

22 Dovoljno je u neku internetsku tražilicu utipkati riječ Bog ili vjera te se odmah nađemo pred mnoštvom različitih tumačenja. U internetskoj komunikaciji nije najveći problem kako doći do informacije, nego »otkriti« koja je informacija istinita. Spadaro tumači da današnji čovjek ima ulogu »dekodera«, tj. da je pozvan između brojnih solucija tražiti pravi odgovor. Usp. A. Spadaro, Cyberteologia, 37-47. 
birati polazeći od osobnih interesa ili želja. Promatrajući način na koji se oblikuju religijski identiteti, Lovheim je zaključio da će današnji čovjek vjerski identitet oblikovati polazeći od vlastite biografije (misleći pritom na prihvaćanje rješenja i odgovora koji bi u većoj mjeri odgovarali osobnim željama). Ne postaje li internetski prostor veoma pogodan humus za oblikovanje vjere koja može (barem u pojedinim aspektima) postati sredstvo i put ispunjavanja osobnih potreba, odnosno odgovor na vlastita traženja? ${ }^{23}$

Ako su religije prije veliku pozornost posvećivale samomu sadržaju, sada, u eri medija, nije dovoljno usredotočiti se samo na sadržaj, nego treba imati u vidu relacije, načine komuniciranja i razmjene koje se u tom kontekstu događaju. Zato se i govor o religiji unutar virtualnog prostora neće ograničiti samo na propitkivanje o istinitosti i autentičnosti (vjerske) poruke, nego će se usmjeriti i na cjelokupni komunikacijski kontekst. Upravo je taj »ekvilibrij«, između sadržaja i načina komuniciranja, za Ravasija najrelevantniji znak promjene u svijetu novih medija. ${ }^{24}$

Memorija je od veoma velike važnosti za mnoge religije. Poznato je kako su primjerice starozavjetni proroci stalno pozivali Izraelce da žive spomen/memoriju na ono što je Bog za njih učinio u povijesti. To nije samo prisjećanje, nego živi spomen, aktualizacija onoga što se dogodilo, a spomen/memorija postaje temelj identiteta vjere zajednice. Općenito se za velike povijesne religije može reći da su veliki »arhivi« kolektivne memorije. Unutar virtualnog svijeta i vlastita se

prošlost ne doživljava kao prijeđeni put koji ima svoj smisao već prošlost jednostavno pada u »zaborav«. Kao da se događa prijelaz od anamneze prema amneziji. Ako bi učestali starozavjetni poziv izraelskom narodu — »sjeti se Izraele! « preveli u naše doba onda bi danas mogli reći nešto sasvim suprotno: prepusti prošlost prošlosti/zaboravu! A s »gubitkom « prošlosti gubi se i perspektiva budućnosti, slabi želja i snaga za žrtvu, za odricanje kako bi se nešto ostvarilo u budućnosti. Put izlaska iz usmjerenosti na samoga sebe uvijek pretpostavlja da se krene od vlastite povijesti, od vlastitog iskustva, od prepoznavanja usmjerenosti vlastitoga života i otkrivanja njegova smisla. Ne radi se samo o »čuvanju « informacija u vremenu, o svojevrsnom »otimanju« zaboravu, već o sposobnosti elaboriranja, očuvanja, odabira i prizivanja. Upravo kao što biblijska memorija nije samo prisjećanje na nešto što se dogodilo već je akcija, djelovanje, uprisutnjenje koje aktualizira prošlo i otvara put prema budućnosti. Cilj koji se želi ostvariti je otvaranje prema stvarnom, realnom životu i ostvarivanju susreta s drugim te otvaranje perspektive za transcendentno. Bez oživljavanja (vlastite) povijesti kao hoda i usmjerenja prema cilju prijeti opasnost da se ostane samo na horizontalnosti. ${ }^{25}$

Bio bi pogrešan zaključak kad bismo rekli da se unutar virtualnih prostora memorija ne oblikuje, da ne postoji. Ona ne nestaje, nego se oblikuje na drugačiji način. ${ }^{26}$

23 Usp. M. Lovheim, Identity, u: H. A. Campbell (ur.), Digital Religion. Understanding religious practice on new media worlds, London - New York, 2012, 52.

24 Usp. G. Ravasi, La richezza del Vangelo anche a misura dei tweet, Vita e pensiero, 1 (2013) 93.

25 J. Valković, Duc in altum! Evangelizacija u »digitalno doba«, Diacovensia, 32 (2012) 2, 183.

26 Usp. J. Ćurković Nimac - I. Sever, Mediji i pamćenje. Prostetičko pamćenje i njegova uloga u stvaranju nove globalne zajednice, u: M. Brekalo (et al., ur.), Kultura, društvo, identitet - Europski realiteti, Osijek — Zagreb, 2014, 416-432. 


\subsection{Novi oblici zajedništva}

Jedno od veoma važnih pitanja koje zaokuplja pozornost komunikologa, sociologa, psihologa, ali i teologa, odnosi se na oblike i narav zajedništva koje se uspostavlja unutar virtualnog prostora i društvenih mreža. Je li moguće i unutar virtualnog prostora ostvarivati autentične oblike zajedništva? Pospješuju li novi mediji povezanost između članova vjerskih zajednica i olakšavaju li pristup osobama koje nisu vjernici?

Nije lako pružiti odgovor na ta i brojna druga pitanja jer o samim zajednicama unutar virtualnog prostora postoje različita razmišljanja. U prijašnjim razdobljima, kako smo već spomenuli, virtualni prostor doživljavao se kao alternativa stvarnomu/realnomu životu, a virtualne zajednice kao nešto što je potpuno odvojeno od svih drugih oblika zajedništva u kojima čovjek živi. U takvoj viziji nije bilo moguće govoriti o istinskom zajedništvu.

Međutim, kako se uočava sve veća povezanost online i offline prostora, sve se više uviđa da nije riječ o nepomirljivim svjetovima, nego o različitim kontekstima unutar kojih se odvija život. I papa Benedikt XVI. rekao je da nije riječi o paralelnim svjetovima: »Digitalni prostor nije paralelni ili čisto virtualni svijet, već je dio svakodnevne stvarnosti mnogih ljudi, napose mladih «. ${ }^{27}$ I tu nalazimo lepezu različitih i nerijetko suprotstavljenih mišljenja. Netko može reći da putem internetske komunikacije osobe mogu veoma uspješno komunicirati, da mogu doživljavati pravu podršku, osjećati se osnaženim u vlastitom identitetu. ${ }^{28}$ Pritom je zanimljivo načelo po kojem se u takvim zajednicama osobe povezuju. Najvećim dijelom članovi grupe biraju se prema kriterijima (zajedničkih) interesa. Na religioznom području to znači da pripadnost određenoj grupi postaje pokazatelj očitovanja vlastitoga kreda. To konkretno znači da se pridružujem onoj grupi ili udruzi u kojoj se bolje osjećam, čije vrijednosti sam dijelim i lako ih prihvaćam.

S druge strane, ima i onih koji bi mogli isticati da komunikacija putem novih medija slabi međuljudsku komunikaciju (face to face) i negativno utječe na izgradnju zajedništva jer pospješuje individualizam. ${ }^{29}$ Stječe se dojam da je virtualni prostor područje vlastite promocije. Zapravo, taj prostor ne otvara prema nečemu što bi nadilazilo pojedinca, usmjeravalo onkraj prisutnog. ${ }^{30}$ (Na vjerskom području to vodi prema snažnoj individualizaciji vjere, na što ukazujemo u tekstu koji slijedi.)

27 Benedikt XVI., Društvene mreže: vrata istine $i$ vjere, 25.

28 Rainie i Wellman ističu da ljudi upotrebljavaju nove medije veoma često u vidu intenzivnije komunikacije, odnosno ti su mediji postali sastavni dio redovitog svakodnevnog komuniciranja. Usp. L. Rainie - B. Wellman, Networked. Il nuovo sistema operativo sociale, Milano, 2012, 192.

29 Takvo stajalište zastupa i Sherra Turkle. O tome posebno govori u knjizi: S. Turkle, Alone Together. Why We Expect More from Technology and Less from Each Other, New York, 2011.

30 Usp. L. Bressan, Diventare preti nell'era degitale. Risvolti pedagogici e nuovi cammini. II, $L a$ Rivista del Clero Italiano, XCI (2010), 176. 
Novost se dogodila širenjem društvenih mreža, što je zapravo značilo novi korak u organizacijskoj strukturi društvenosti unutar virtualnog prostora. ${ }^{31}$ Umjesto različitih oblika (virtualnog) zajedništva, u prvi plan je došao pojedinac i u središtu su osobni kontakti koje je on uspostavio. Zato su i poruke u takvom okruženju prvenstveno adresirane upravo pojedincima ili manjim grupama.

Kako promatrati takve zajednice i odnose koji se uspostavljaju? Zajednice i odnosi koji se oblikuju u virtualnom prostoru ne mogu se promatrati odvojeno od cjelokupnog društvenog (offline) konteksta u kojem živi današnji čovjek i cjelokupno društvo jer ne postoje (tako čvrste) granice između virtualnog i realnog svijeta. Tako je primjerice poznato da su povezanosti i zajednice koje se oblikuju $\mathrm{u}$ virtualnom prostoru veoma nepostojane. Međutim, to nije samo karakteristika virtualnih zajednica, nego takvu situaciju treba promatrati u širem kontekstu cjelokupnog postmodernog društva. A jedna je od karakteristika nestalnost svih oblika povezanosti. ${ }^{32}$

Već spomenuta krhkost nikako ne znači da zajedništva i povezanosti između ljudi u tom prostoru nema. I na tom području treba imati u vidu određenu »stupnjevitost «. Teolog Rahner, kada govori o važnosti povezivanja za zajednicu Crkve, kaže da je svako ostvarenje ljudske društvenosti, pa i ono koje tek počinje klijati — iako veoma široka i proširena — aktualizacija Crkve..$^{33}$

Polazeći od dostupnosti vjerskih tema i sadržaja na Internetu, veoma jednostavnog uključivanja i mogućnosti da sudionici ostaju anonimni, Internet za mnoge može postati »predvorje«, prvi kontakt koji uspostavlja s nekom religijom. Zacijelo je uspostavljanje kontakata na različite načine jedna od prednosti novih medija, koje uočava i papa Benedikt XVI. kada kaže: »Te su tehnologije pravi dar za čovječanstvo: moramo zato učiniti da se prednosti koje one pružaju stave u službu svih ljudi i svih zajednica. $\ll^{34}$

Ali isto tako treba ukazati i na neka područja u kojima se može vidjeti ograničenost medija. To je veoma konkretno vidljivo kod prijenosa liturgijskih slavlja. Naime, vjerski život pretpostavlja (fizičku) blizinu i susrete, osobito kad je riječ o primanju sakramenata (tu mislimo na sakramente u Katoličkoj crkvi). Nijedan medij ne može »komunicirati« sakramente jer medij redovito prenosi samo sliku i zvuk, odnosno ritualnost, a autentično sudjelovanje pretpostavlja fizičku prisutnost, odnosno dioništvo u zajednici koja slavi. Medij isto tako ne može omogućiti prisutnost u liturgijskom događaju na način kako to, po svojoj naravi, liturgija pretpostavlja.

31 Usp. L. Paccagnella - A. Vellar, Vivere online. Idenitità, relazioni, conoscenza, Bologna, $2016,71$.

32 Između brojnih djela koja govore o karakteristikama postmodernog društva i čovjeka spomenut ćemo djelo: Z. Bauman, Tekuća modernost, Zagreb, 2011.

33 K. Rahner, Corso fondamentale sulla fede. Introduzione al conetto di cristianesimo, Roma, 1978, 414.

34 Benedikt XVI., Nove tehnologije, novi odnosi, 26. 


\subsection{Individualizacija — »Sveto ja«}

Nije tu riječ o »nestajanju «svetog, o smrti Boga ili religije, nego o ukazivanju na individualizaciju i stavljanju samoga sebe na mjesto Svetog. Time se želi ukazati na promjenu vjerskog iskustva kako se događa kod današnjeg čovjeka. Više je čimbenika koje utječu na tu promjenu: promjena odnosa i načina komunikacije između pojedinaca i zajednice, oslabljena uloga (vjerskog) autoriteta te sve jača uloga osobe u traženju i selektiranju (čak i) sadržaja vjere. Sve to pospješuje proces »organiziranja« vjere po vlastitoj mjeri.

Novi oblici povezivanja koji se ostvaruju osobito u komunikaciji kroz društvene mreže u prvi plan stavljaju pojedinca. ${ }^{35}$ »Sveto « je unutar virtualnog »prisutno« na drugačiji način. Zapravo, ne legitimizira Sveto službeni autoritet, nego je »legitimizacija « prepuštena izboru pojedinca. Jedno od svojstava takve religioznosti je da se ona ne temelji na »privučenosti« od Svetog, nego je u prvom planu traženje osobe koja tim putem želi zadovoljiti vlastite potrebe i ostvariti se uz pomoć »Svetog ja«. Riječ je o tome da je postmoderni čovjek sklon kroz vlastitu religioznost tražiti put ostvarenja i realizacije, tako da čak i religija postaje sredstvo za ostvarenje tog cilja. ${ }^{36}$ I u odnosu prema Svetomu želi se slijediti put koji odabire pojedinac. Giordan i Pace još su snažnije naglasili tu okolnost današnjeg vjerovanja ističući da danas »sveto ja « postaje jedini »autoritet«kojeg treba slijediti. Riječ je o promjeni koju oni označavaju prijelazom od religije ka duhovnosti s naglašenom »kreativnom « ulogom pojedinca. ${ }^{37} \mathrm{U}$ takvoj religioznosti kao da je riječ o vjeri koja se temelji i koja polazi od sinkronizacije s vlastitim osjećajima i vlastitim prosudbama. Gotovo kao da je u prvom planu ne toliko (objektivna) istina prema kojoj se želi usmjeriti, nego subjektivna autentičnost. Zato i takav obrat prema vlastitoj nutrini ima za posljedicu da se sve veća pozornosti daje emocijama, doživljajima, strastima i življenomu iskustvu. ${ }^{38}$

Pomicanje naglasaka od legitimizacije Svetog od vjerskih institucija prema samoj osobi otvara pitanje doživljaja i uloge autoriteta.

\subsection{Autoritet}

Kako se doživljava autoritet u virtualnom prostoru? Je li doista riječ o takvim promjena da se može govoriti o novoj ulozi, odnosno novim odnosima koji se prema autoritetu uspostavljaju? Treba odmah spomenuti da se o ulozi autoriteta nije počelo promišljati tek s pojavom internetske komunikacije jer se primjerice i kod pojave tiska uočavaju promjene koje je donijelo to sredstvo društvene ko-

35 Usp. M. Castells, Gallassia Internet, Milano, 2010, 123.

36 Pojam »sveto ja« opširnije je obrađeno u knjizi: G. Giordan (ur.), Tra religione e spiritualita. Il rapporto con il sacro nell'epoca del pluralismio, Milano, 2006.

37 Usp. E. Pace - G. Giordan, La religione come comunicazione nell'era digitale, Humanitas, 5-6 (2010), 777.

38 Upućujemo na knjigu u kojoj se na opširan način govori o današnjem poimanju individualizma: C. Taylor, Izvori sebstva — razvoj modernog identiteta, Zagreb, 2011. 
munikacije. ${ }^{39} \mathrm{U}$ novije vrijeme ta tema postaje aktualna širenjem elektroničkih medija, osobito televizije. Mediji utječu na društvenu hijerarhiju tako što utječu na globalnu ravnotežu između lidera i onih koji ih slijede. ${ }^{40}$ Zapravo, pojava svakog novog medija, smatra Joshua Meyrowitz, aktualizira pitanje autoriteta jer se »autoritet temelji na kontroli informacija «. ${ }^{41}$ Televizija omogućava širokomu krugu ljudi neposredan pristup informacijama, tako da i one više nisu privilegij određenih elita. Naime, pripadnost grupi bila je redovito povezana s mogućnošću pristupa ili raspolaganja informacijama koje su vezane uz tu grupu. Zato se u društvenom životu ulazak u neko društvo uvijek odvijao postupno, a nerijetko se taj čin ulaska obilježavao i ritualima. Time nestaju »barijere« koje su definirale pripadnost određenomu krugu. Isto tako, kada je riječ o autoritetu, njegova pozicija više nije »zagarantirana« isključivim pristupom ili posjedovanjem određenih informacija jer su one - velikim dijelom i zbog djelovanja medija — dostupne drugima.

Šrenjem internetske komunikacije to pitanje postaje ponovno aktualno. Naime, Internet mijenja način na koji komuniciramo s drugima, na drugačiji način oblikuje shvaćanje autoriteta, stvara nove pozicije moći, nivelira tradicionalne hijerarhije i omogućava platforme koje daju mogućnost glasa i onima koji nemaju glasa ${ }^{42}$ Ono što obilježava komunikaciju novih medija je »decentralizacija jer se ne komunicira iz središta prema »periferiji«. Autoritet se u virtualnom prostoru ne temelji na hijerarhijskom načelu jer Internet, po svojoj organizaciji i načinu kako komunicira, razvija horizontalnu komunikaciju. Riječ je o velikoj promjeni i zato mnoge velike religije mrežne stranice doživljavaju još uvijek kao novo sredstvo u evangelizacijskom djelovanju, pri čemu, vođeni logikom tradicionalnih institucija, zadržavaju komunikacijski stil top-down. ${ }^{43}$

Zanimljivo je promišljanje Pauline Hope Cheong koja je predstavila tri načina na koja Internet može utjecati na oblikovanje uloge autoriteta religijskih lidera i institucija. ${ }^{44} \mathrm{U}$ prvom redu smatra da se internetskom komunikacijom može utjecati na način kako će jedna zajednica shvaćati i formirati svoj religijski identitet. Zato, u prvom razdoblju kada je prevladavao stav suprotstavljanja online i offline prostora, Internet se doživljavao kao pogodno sredstvo za alternativne informacije koje na neki način stavljaju u pitanje tradicionalno naučavanje. To

39 O tome detaljnije: J. Valković, Crkva i svijet medija. Mogućnosti susreta i različitost perspektiva, Zagreb, 2013, 19-23.

40 Usp. J. Meyrowitz, Oltre il senso del luogo. L'impatto dei media elettronici sul comportamento sociale, Milano, 1995, 264.

41 Isto, 263.

42 Usp. H. Campbell - P. E. Teusner, Religious Authority in the Age of the Internet. URL: http:// www.baylor.edu/content/services/document.php/130950.pdf, 59 (preuzeto 15.12.2015.)

43 Analizirajući neke medije u Katoličkoj crkvi, Domanin i Porro pišu da se dobiva dojam kako se u virtualnom prostoru »dogodila virtualna transportacija papinske ekspozicije ex catedra ${ }^{\circ}$. Crkva kao da govori isti jezik koji susrećemo na stranicama knjiga. I. Domanin - S. Porro, Il web sia con voi, Milano, 2001, 40.

44 P. H. Cheong, Authority, u: H. Campbell (ur.), Digital Religion. Understanding religious practice on new media worlds, London - New York, 2012. 
je veoma pogodan prostor za širenje raznih pokreta ili učenja koja mogu biti suprotna službenomu naučavanju. Nadalje, kada se u internetskoj komunikaciji favorizira suglasje između online i offline aktivnosti, zapravo se osnažuje komplementarnost između internetskog djelovanja/komunikacije i samog autoriteta. Time se pozicija autoriteta ne samo potvrđuje nego i osnažuje i to kroz online djelovanje. Zato Cheong kaže da vjerski vođe u razvoju Interneta vide važno sredstvo potpore za svoje djelovanje. ${ }^{45}$ Treći način djelovanja vidi u dijalektici i paradoksu. Internet može jačati ali i slabiti vjerski autoritet jer može isticati konflikte koji su prisutni ili, s druge strane, opravdavati pojedine odluke autoriteta, čime utječe na status autoriteta.

Najprihvatljivija je teza O'Neila da Internet ne eliminira značenje i ulogu autoriteta, nego je ispravno govoriti o nastanku novih oblika autoriteta. ${ }^{46}$

\subsection{Internet — put izgradnje globalne obitelji!}

Djelovanje mnogih vjerskih zajednica kroz stoljeća bilo je organizirano i vezano uz teritorijalno (određena) područja (primjerice u Katoličkoj crkvi temeljna je zajednica župa). U virtualnim prostranstvima mnoge kategorije (primjerice vremena i prostora) doživjele su transformaciju. Pred tim promjenama i vjerske zajednice osjećaju potrebu prilagođavanja. Upravo pitanje pripadnosti danas postaje aktualno ne samo kada se govori o virtualnim prostorima nego i u kontekstu globaliziranog svijeta jer to utječe i na osobni i zajednički život. A to se iskustvo, upravo u vrijeme velike mogućnosti komunikacije $\mathrm{i} \gg$ boravka « $\mathrm{u}$ virtualnom prostoru, veoma promijenilo. Giaccardi i Magatti tvrde da najveći izazov današnjeg društvenog prostora nije u suočavanju s društvenim poretkom kojeg bismo trebali prihvatiti ili mu se suprotstaviti, nego u tome da se trebamo suočavati s iskustvom koje nije cjelovito. Zbog tog »fragmentiranog « iskustva sve je teže doživljavati smislenu cjelovitost. ${ }^{47}$

Iako unutar virtualnih prostranstava ne nalazimo odrednice ili kriterije djelovanja koje nalazimo u realnom svijetu, u tim se prostorima krećemo polazeći od obilježja i karakteristika (fizičke) zajednice kojoj pripadamo. Takvo iskustvo koje posjedujemo živeći u stvarnom svijetu postaje na neki način polazište ili smjernica za kretanje u virtualnom prostoru. Tako Baym, govoreći o offline iskustvu, smatra da ono osobito utječe na argumente, načine kako o njima raspravljamo, etičke stavove koje zauzimamo u online diskusijama i dr. ${ }^{48}$

Benedikt XVI. pred nove medije postavio je veliku zadaću. Naime, naše sudjelovanje u ljubavi Božjoj potiče nas da cjelokupno čovječanstvo usmjeravamo prema izgradnji jedne obitelji.

45 Usp. Isto, 79.

46 Usp. M. O'Neil, Cyber Chiefs. Autonomy and Authority in Online Tribes, London - New York, 2009, 169.

47 Usp. C. Giaccardi - M. Magatti, L'io globale, Roma - Bari, 2003, 166-167.

48 N. Baym, Personal Connections in the Digital Age, Cambridge, 2010. 
Kada osjećamo potrebu približiti se drugim osobama, kada ih želimo bolje upoznati ili pak želimo da drugi nas upoznaju, odgovaramo na Božji poziv — poziv koji je utisnut u našu narav bića stvorenih na sliku i priliku Boga, Boga komunikacije i zajedništva. Želja za povezivanjem s drugima i nagon komunikacije, koji su nešto što se u suvremenoj kulturi samo po sebi podrazumijeva, nisu u stvari ništa drugo već suvremene manifestacije temeljnog i konstantnog nagnuća ljudi da se odmaknu od samih sebe kako bi stupili u odnos s drugima. Kada se otvorimo drugima, mi zapravo ispunjavamo naše najdublje potrebe i postajemo potpuniji ljudi. ${ }^{49}$

Komunikacija putem Interneta i općenito putem društvenih mreža izvanredno je sredstvo za povezivanje, upoznavanje i komuniciranje, ali isto tako razvijanje solidarnosti na širim globalnim razinama. Možda je potrebno, na tragu Benedikta XVI., i u okruženju novih medija gajiti iskonsku želju čovjeka za povezivanjem i zajedništvom, za ostvarenjem globalne ljudske obitelji.

\section{Zaključak}

Kroz povijest religije su više puta bile pred izazovom inkulturacije u novu kulturu. I Katolička crkva, kako je to istaknuo papa Ivan Pavao II., trebala je prijeći mnogobrojne kulturalne pragove. ${ }^{50}$ Proučavanje današnja kulture, u kojoj komunikacijske tehnologije i procesi zauzimaju veoma važno mjesto, izazov je vjerskim zajednicama ne samo za efikasnije djelovanje, nego su pozvane suočiti se s mnogim pitanjima antropološkog i religijskog karaktera.

Komunikacijski model koji su mnoge religije stoljećima primjenjivale (utemeljen na »kulturi knjige«) i danas je također prisutan, ali nije jedini i nije toliko dominantan. Novi mediji oblikuju nove komunikacijske modele koji prožimaju život današnjeg društva i pojedinaca. Nema danas nijednog područja ljudskog života koji bi bio izuzet od njihova utjecaja.

Religija na Internetu je (relativno) nova tema, kojoj će se trebati posvećivati veća pozornost. Ono što se već sada može reći je da se nalazimo na početku jednog procesa koji duboko zahvaća ne samo međuljudsku komunikaciju (na svim razinama), nego utječe i na religijsko iskustvo. Interdisciplinarni pristup, uz intenzivni dijalog teološko-humanističkih i komunikacijskih znanosti, nužan je za razumijevanje (promjena) unutar religije kada zalazi u virtualne prostore, ali isto tako izgradnji autentične komunikacije i zajedništava. 
Religion and the Internet — New Challenges to Living the Faith

Krunoslav Novak*, Jerko Valković**

Summary

The new media are not only a means of communication, but an »atmosphere in which millions of people throughout the world »live on a day-to-day basis. This is a space within which new means of communication are developed, and there occur new ways of linking and forming of new communities. Considering the fact that we live »in « and »with « the virtual world and that it strongly affects daily life, the authors reflect on how life in the virtual world affects the experience of faith. In the paper, special attention is devoted to the impact of internet communication on certain crucial determinants of faith: virtual symbolic context, new forms of communities, the question of authority, individualization and the sense of belonging.

Key words: religion and the internet, religion on-line, on-line religion, authority, community, belonging

* Krunoslav Novak, Ph.D., Department of Communication Sciences, The Catholic University of Croatia, Zagreb, Croatia. E-mail: krunoslav.novak@unicath.hr

** Associate Professor Jerko Valković, Ph.D., Department of Communication Sciences, The Catholic University of Croatia, Zagreb, Croatia. E-mail: jerko.valkovic@gmail.com 